\title{
Perspective: OECD Draft Transfer Pricing Guidelines
}

\author{
Toshiaki Katsushima, Deloitte \& Touche, Tohmatsu, Tokyo
}

The initial reactions to the OECD's Committee on Fiscal Affairs' discussion draft of Transfer Pricing Guidelines for Multinational Enterprises and Tax Administration, Part $\mathrm{II}^{1}$ have been, on balance, favorable. I believe that an overall favorable reaction is justified. These draft guidelines, just like Part I, take a rationale, pragmatic approach to transfer pricing. This is not to suggest that there is no room for improvement in the report. The draft report could use some changes and modifications, some of which I will touch on a little later.

The overriding issue to me is whether the OECD transfer pricing guidelines (Parts I and II) provide well considered, workable transfer pricing rules which will help assure the integrity of the national tax systems and minimize the potential for double taxation.

The significance of this consideration is that, today, we live in a truly global marketplace. Goods, money, know-how and services are highly mobile and seemingly cross borders at will. In my practice, I regularly see young entrepreneurial companies developing international distribution networks for their products, and even services. Accordingly, the economies of the world are interdependent. Consequently double taxation is an economic disincentive to be avoided.

One only has to turn to recent events between my country and the US regarding automobiles and auto parts for an example of the global economy and the potential adverse economic impact of disagreements between governmental agencies of two nations.

Therefore, it is in the interest of both businesses and tax authorities that double taxation is avoided. The only way to accomplish this is internationally accepted, and applied, transfer pricing rules. The OECD transfer pricing guidelines, subject to some changes and modifications, should be these rules.

Turning back to OECD Part II, draft guidelines, I offer a few brief comments and observations (I will leave the detailed commentary for my colleagues contributing to this edition of the journal):

- The OECD drafters did a fine job of defining 'intangibles,' especially marketing intangibles. However, the drafters indicate, 'when the royalty is based on the licensee's output or sales, a payment computed on a digressive basis (...) may be common. ${ }^{2}$ The report should also include a statement that a royalty based on a progressive basis is just as common in practice. This may be the case when the developer/exploiter of the intangible wants to penetrate the marketplace.

- The draft report correctly expresses reservations about the application of transaction based methods in cases involving highly valuable intangible property because of the difficulty of obtaining comparables. ${ }^{3}$ Accordingly, the draft report suggests in these circumstances to look to profit methods. The draft report recommends using a residual profit split method. I agree that the profit split method is appropriate in the case of valuable intangibles. However, the language of the report seems to permit the use of CPM. My experience with CPM and intangibles is that its use leads to distorted, unrealistic results, more so than transfers of tangible property. Accordingly, the OECD should not permit the use of CPM in cases of transfers of $\mathrm{v}$ :uable intangibles. (I would also urge the OECD Fiscal Affairs' Committee to revisit the permissibility of CPM as a transfer pricing method because it is inconsistent with the arms' length principle.)

\section{$\pi$}

\footnotetext{
' Part II covers the application of transfer pricing principles to transfers of intangibles, services, cost contribution arrangements, penalties, documentation and other tax administration issues.

2 Para. 15.

3 Para. 25.
} 
- This discussion regarding intra-group services is detailed and provides good guidelines. However, it appears too weighted towards the recipients of the services.

- The drafters wisely suggest a common sense approach to penalties given the subjective nature of transfer pricing determinations. ${ }^{4}$ However, the draft report on penalties is more in the nature of an exhortation. The final report should include a declaration, as one of its principles, that only fair and reasonable penalties are acceptable.

- Kudos to the Committee for their section on arbitration and their agreement to study and report on the matter. It would be nice if tax systems caught up with other areas of commerce in resolving international disagreements.

- The OECD drafters wisely took a middle path on documentation requirements. Their recommendations fall somewhere between what companies may consider necessary and what tax authorities may consider necessary. One question is what impact the standard recommended by the OECD will have on the documentation requirements of the final US penalty regulations under IRC para. 6662 .

In closing, the Committee members should be commended for their work. They accomplished a Herculean task of reconciling the tax regimes of the various countries, yet maintaining the crucial arms' length principle; and thus, obtaining the consensus of the Committee members. The only drawback to their approach is that the transfer pricing guidelines will not be theoretically perfect. However, I can live with imperfection if it means an internationally accepted set of transfer pricing guidelines that are consistently applied by national tax authorities.

The critical question is will the tax authorities (and governments) of the developed and developing nations be far sighted enough to adopt the guidelines and/or conform their existing transfer pricing laws and regulations to the finalized OECD transfer pricing guidelines. For the sake of our global economy, I hope so.

\footnotetext{
${ }^{4}$ Para. 143.
} 